\title{
QUANDO A PROSA DANÇA E A DANÇA CAMINHA
}

\author{
Ana Marques Gastão \\ (Poeta, ensaísta, crítica literária)
}

\section{RESUMO}

Para Paul Valéry, como o andar, a prosa segue o caminho da menor acção; a linha direita, e a poesia, como a dança, enquanto "sistema de actos", não só não vai a lado nenhum, como se realiza em si mesma, institui a sua própria finalidade. Mas por que razão tem a prosa esse impulso comandado, impulsionado pelo desejo, e a poesia não, quando tantas vezes são uma só, e vice-versa?

Enquadrando, na perspectiva coreográfica, conceitos como a marcha e a dança, a propósito de obras como as de Rainer Maria Rilke, Fernando Pessoa, António Vieira e Yvette K. Centeno, desenvolve-se, neste texto, a ideia de, amiúde, ser impraticável e inútil a distinção entre géneros. Mesmo sendo possível - e apesar de esta questão ter ocupado teóricos de todos os tempos - a que leva tal procedimento? Por que não pode a prosa ser dançável e a poesia caminhante?

O ser que anda pode ou não ser um bailarino do inconsciente?

PALAVRAS-CHAVE: Poesia-prosa, Dança, Marcha.

\section{ABSTRACT}

To Paul Valéry, prose follows the weakest action path, as in marching in a straight line, and poetry, as in dancing - in as much as it is a «system of acts» - it not only intends to go nowhere but it remains in its own realisation, creating its own purpose. Why then does his prose contain this commanded impulse, led by desire, and his poetry does not, since they are so often one and the same?

In this essay, looking at works by Rainer Marie Rilke, Fernando Pessoa, António Vieira and Yvette K. Centeno, I develop the idea that, very often, to establish a distinction between genres can be impractical and useless, if one considers concepts such as march/walk and dance from a choreographic perspective. Even if it be a possible question and since it has nevertheless been the object of study by scholars of all times, why is it undertaken? Why can't prose be danced to, and poetry marched to?

Can the walking essence unconsciously dance?

KEYWORDS: Poetry-Prose, Dance, Walk. 
É contrário à natureza da poesia tentar defini-la ou enquadrá-la no processo de formatação de um texto, levando-a a esconder-se por entre as gavetas virtuais do inferno tecnológico. Seria como tentar explicar, em vez de simplesmente reconhecer, o cheiro de mínimas violetas que nos diz de como as moléculas estremecem no ar invadindo acidentalmente o nosso nariz. Hoje os químicos explicam-nos exactamente o porquê desse fenómeno, fornecendo-nos dados sobre a combinação dos átomos no espaço. Situam-nos, enfim, nos corredores de uma viagem inusitadamente aerífera.

Tentar distinguir a poesia da prosa, tema que ocupou teóricos de todos os tempos, dir-se-ia função não só eternamente inacabada como eivada de impossibilidades. Se a diferença entre ambas não se detém nas ideias veiculadas pelo discurso, os constrangimentos formais não são, por outro lado, suficientes para determinar a qualidade poética de um texto. Se há muito se recusou o ideal clássico de Voltaire de que a poesia deveria ser entendida como "eloquência harmoniosa", a verdade é que esta nasce, em regra, de uma tensão oposta a uma linguagem de comunicação coerente.

À língua, enquanto produto social, propriedade do conjunto dos homens, submetida a códigos que asseguram a comunicação, opõe-se a palavra poética, acto individual e criador do domínio da liberdade, da imaginação e da fantasia ${ }^{1}$, o que não impede que essa erupção presente-ausente aconteça no discurso prosador de matéria mais obviamente significante: nem poesia nem prosa, mas um meio-termo, algo que Giorgio Agamben acentua, a partir do testemunho de Aristóteles (AGAMBEN, 1998, p. 24). Ou seja, o poeta é um transgressor, ser dúplice que não está nem cá, nem lá, criança-órfã que subverte uma suposta ordem sagrada. Poeta pelicano que hesita entre o som e o sentido, desdobrando-se, justapondo-se, expondo-se.

A ideia de que a poesia se inventa a ela própria contra a língua marcou, no entanto, a reflexão de autores como Baudelaire e Mallarmé, Valéry ou Jean-Paul Sartre. Para o autor de L'Étre et le néant, aquela serve-se dos meios da prosa mas não da mesma forma: "Os poetas são homens que se recusam a usar a linguagem" (SARTRE, 1948, p. 63), utilizando as palavras, numa dimensão interrogativa absoluta, em estado selvagem. A emoção torna-se coisa. Escrever é, nesse sentido agir, como, aliás, falar: "Porque a intuição é silêncio e a finalidade da linguagem é comunicar" (SARTRE, 1948, p. 72). Já Octavio Paz vê o poema enquanto linguagem em tensão, separando-o, como Valéry, da prosa (género tardio, ao contrário da poesia), que considera teoria de ideias ou factos:

Os arquétipos da prosa são o discurso e o relato, a especulação e a história. O poema, pelo contrário, oferece-se como um círculo ou uma esfera, algo que se fecha em si mesmo, universo auto-suficiente no qual o fim é também um princípio que volta, se repete e se recria. E esta constante repetição e recriação não é senão ritmo [a linguagem nasce dele], maré que vai e vem. Cai e levanta-se. (PAZ, 2004, p. 69) ${ }^{2}$

Ao revelar-se como realidade meramente ornamental, a poesia deixa, todavia, de ser poesia e, se se deixa possuir por uma versificação domesticada, pelo totalitarismo do exercício escolar ou se converte em kleine Musik, nega-se a si mesma enquanto género. Mesmo respeitando as regras da métrica clássica, textos há que não podem considerar-se poemas. $\mathrm{O}$ verso livre, o poema em prosa apagaram, por outro lado, fronteiras de antes, 
que enclausuravam a ideia na manipulação formal, tornando-a proposição contratual entre pressentimento linguístico e confusão de frases modelares reveladas por um hipotético e oco estilo, forma de terapia sonora e volúvel contra os maus ventos.

Mas de onde vêm certos textos aos quais chamamos poemas e que nos arrancam da linguagem comum, mesmo que, por vezes, a utilizem? De um intervalo silencioso entre a experiência vivencial e a literária? De uma paragem entre ruído e calamento? Da chave da consciência e da sua excentricidade encontrada no inconsciente? Sendo, como referiu Paul Valéry, "arte da linguagem, linguagem dentro de uma linguagem", "criação de uma prática" (VALÉRY, 2002, p. 672), a poesia lida com a substância das palavras, na acepção de Ponge, (1984, p. 89) e realiza-se como se fruísse de uma energia activa com luminosidades múltiplas que se vão deformando ao defrontarem-se com obstáculos de ordens diversas (questões formais, imagéticas ou de som e sentido), tal como a tinta que, ao derramar-se, fluida, no papel, acaba por combater, ziguezagueando, as elevações e descensões de diferentes texturas, encontrando, assim, caminhos vários e inesperados.

Imagine-se a navegação do sangue - associado à cor vermelha e que simboliza todos os valores solidários do fogo, do calor e da vida quando realiza a respiração celular, transportando oxigénio e parte do anidrido carbónico pela hemoglobina, ou a estrutura dos leucócitos, que formam verdadeiros exércitos contra os microrganismos causadores de doenças sempre que qualquer partícula estranha penetra no organismo. A escrita tem pontos em comum, até na dimensão visual, com este movimento de resistência que pode ainda ser entendido na perspectiva da corrente eléctrica ou da mecânica. Escrever é essa capacidade de um corpo/cérebro/ coração se opor à paragem, transporte esforçado de um peso que, no atrito e na fricção do seu suporte, vai eliminando a escuridão e a ausência, permitindo viagens reconstitutivas do espaço vazio que, sob a forma contraída de um raio de luz-energia, tornam o caminho, enquanto actividade antropológica, não uma cicatriz na terra, mas celebração. Escrever reconstitui a rotina pelos degraus de uma biblioteca infindável e invisível.

\section{Poesia: luz de escuridão actuante}

Nessa medida, a poesia dir-se-ia luz de escuridão actuante (porque a atravessa), movimento (no sentido eléctricomagnético) de retrocesso e avanço, subida e descida, jogo de contrários, concentração, contracção ou distensão do corpo-palavra, algo que a física moderna poderia explicar, não deixando de ser sinónimo de um conflito etológico-simbólico entre o pássaro (espírito) e a serpente (matéria). Não são todas as coisas feitas de átomos - pequenas partículas que agem em perpétua deslocação, atraindo-se e repelindo-se mutuamente como se a extensão das coisas fosse mínima?

Esse tipo de organicidade não é alheio à literatura, seja de que tipo for, nem aos modos de funcionar da mente, se entendermos o mundo como um grande cérebro patibular que vai transformando em imagem tudo o que entendemos por realidade. A palavra - ou um seu regresso -, dir-se-ia, por outro lado, o dínamo que faz avançar a partir da acção da experiência, o que implica um saber de silêncio e suspensão de uma temporalidade. É Rilke quem escreve em As Anotações de Malte Laurids Brigge: 
Pois os versos não são, como as pessoas julgam, sentimentos (esses aparecem bastante cedo) - são experiências [...] E também não basta ter recordações. É preciso poder esquecê-las quando são muitas, e é preciso ter a grande paciência de esperar que elas regressem. Pois as próprias recordações ainda não são o que mais importa. Só quando se tornam sangue dentro de nós, olhar e gesto, quando deixam de ter nome e já não se distinguem de nós mesmos, só então pode acontecer que, no decurso de uma hora muito rara, a primeira palavra de um verso delas se erga e delas saia. (RILKE, 2003, p. 48-9)

Os versos do autor de Sonetos a Orfeu são e não são versos, como ele próprio sublinha, a sua prosa é e não é prosa, o que se torna paradigmático quanto à quase impossibilidade de, em certos casos, se distinguir entre géneros. O texto de Rilke caminha e dança, unindo o que Valéry considera separável - poesia e prosa -, equilibrando-se, por entre quedas, descendo fundo, em vez de subir, na linha direita da prosa, que, por vezes, ziguezagueia, ou escorregando na zona curvilínea do poema, que pode tornar-se plano, habitando o discurso num lugar em que a mão já não pertence ao autor e onde se é escrito3: "Sou a impressão que se vai transformar [...]. Mais um passo e a minha profunda miséria transformar-se-ia em bem-aventurança." (RILKE, 2003, p. 73)

Estamos, claro - para além da ideia do sangue enquanto símbolo de um corpo invisível -, perante um fenómeno conjugado da psique, representada, do ponto de vista analítico, em diversos andares à semelhança do palácio dos alquimistas, repartido entre o inconsciente (o segredo), o consciente (o poder e a ciência) e o subconsciente (o tesouro ou o ideal) (CHEVALIER-GHEERBRANT, 2005, p. 723). Ou seja, a transformação da linguagem opera-se, não só por associação à capacidade de esquecimento, mas, sendo concebida para além de, à maneira dos românticos (LACOUE-LABARTHE-J.L. NANCY, 1978, p.278), pela metamorfose do sujeito primitivo, sendo a escrita não necessariamente, do ponto de vista formal, isto ou aquilo.

Escreve-se, portanto, na errância das palavras, com a seiva/tinta de uma árvore/corpo que é, no fundo, o eixo central - a coluna vertebral - de um trajecto interior e cuja exterioridade funciona como pele de um corpo fragmentário que respira na articulação entre os ossos do pensar e a carne da emoção. Embora a filosofia racionalista considere que, onde a razão perde os seus direitos, nada mais há, o escritor, sendo artífice de instrumentos epistemológicos, não se define pela mera limitação do real. $\mathrm{O}$ real é irreal. O universo, antes da invenção do óculo de Galileu, estava lá, mas era invisível, ou seja: o que se modificou foi a medida do nosso saber.

Valéry, consciente dessa exaltação da realidade tornada indestrutível pela experiência, debruçou-se, nas suas conferências, retomadas depois em textos ensaísticos, sobre a "oposição", sempre discutível, entre poesia e prosa. A seu ver, como o andar, a prosa segue o caminho da menor acção; quer dizer, a linha direita, e a poesia, como a dança, enquanto "sistema de actos", não só não vai a lado nenhum, como se realiza em si mesma, institui, conforme acrescenta, a sua própria finalidade. 
La marche, comme la prose, vise un objet précis. Elle est un acte dirigé vers quelque chose que notre but est de joindre. Ce sont des circonstances actuelles, comme le besoin d'un objet, l'impulsion de mon désir, létat de mon corps, de ma vue, du terrain, etc., qui ordonnent à la marche son allure, lui prescrivent sa direction, sa vitesse et lui donnent un terme fini. (VALÉRY, 2002, p. 679)

Haveria que precisar, para melhor compreensão deste excerto, a noção de "objecto definido" que o andar visa. Não sendo intuito do escritor a mera construção de uma narrativa, pressupõe-se que nele haverá um desejo de autoconhecimento e de sabedoria, revelado no curso da prosa. A investigação lida, todavia, com o incerto e o desconhecido. Preocupada mais com o caminho do que com a chegada (a Ítaca de Kavafis), por que razão tem a prosa esse impulso comandado, impulsionado pelo desejo, e a poesia não, quando tantas vezes são uma só, e vice-versa?

Salomão, citado por Nicolau de Cusa (2003, p. 4), considerava que "todas as coisas são difíceis e inexplicáveis pela linguagem" $(E c l 1,8 .)^{4}$, o que torna manifesta a ideia de Sócrates de que a viagem só pode ser a do saber que se ignora. Não há outro trilho para o estudioso/viandante que o autêntico escritor/poeta é. Talvez por isso Rilke, no seu diário florentino (RILKE, 1946), defina a via do artista como uma caminhada ${ }^{5}$ na qual se vão, passo a passo, ultrapassando obstáculos até que aquele possa olhar-se a si próprio de modo tranquilo e com clareza como se estivesse a contemplar uma paisagem. Escrever não deixa de ser um trabalho/serviço do olhar e da escuta nos seus aspectos de alteridade interna. Não será o sujeito a ascese do indivíduo e a arte uma forma de, a partir do caos, se tornar organização subjectiva?

Referindo-se à dança, Valéry compara-a, porém, com a poesia e não com a prosa:

La danse - leia-se poesia - [...] si elle poursuit quelque objet, ce n'est qu'un objet idéal, un état, un ravissement, un fantôme de fleur, un extrême de vie, un sourire - qui se forme finalement sur le visage de celui qui le demandait à l'espace vide.» [...] Il s'agit donc, non point d'effectuer une opération finie, et dont la fin est située quelque part dans le milieu qui nos entoure; mais bien de créer, et de entretenir en l'exaltant, un certain état, par un mouvement périodique qui peut sexécuter sur place; mouvement qui se désintéresse presque entièrement de la vue, mais qui sexcite et se règle par les rythmes auditifs. (VALÉRY, 2002, p. 679-80).

Teríamos, em primeiro lugar, que definir o conceito de ideal associado a uma capacidade de escuta submetida ao ritmo, esse poético, rilkiano e inacabado "sopro" em torno de nada, como algo (mental ou imaginário) que não sendo é - ou a que se aspira na acepção platónica. Seria um ponto de partida, mas, a indagação subsiste: por que motivo não pode a poesia, se assim se pode dizer, ser andante, caminhante? Por que não pode a prosa, sobretudo quando fragmentária, ser dançável até pela existência de uma découpage analítica do espaço numa dimensão orientada, algo que Rudolf Laban $^{6}$ estudou a partir de 26 direcções emanando do centro do corpo e da sua kinésphère? ${ }^{7}$ 
Valéry não terá tido em conta, ao afirmar que a dança/poesia é um movimento quase desinteressado da visão (como se os sentidos não estivessem interligados), que ela é inconcebível sem o olhar, sob pena da perda de equilíbrio, e sobretudo sem a visualização, modo de representação mental coreográfica que, na escrita, passa pelo enquadramento espacial na página. Ou seja, dançar, como escrever poesia, depende de processos perceptivos e da manipulação da visão interior/exterior ou imagética, esta gerada de forma activa. A coordenação do corpo por meio do atento fixar da visão não só define a concentração, a organização postural (e as mudanças de direcção), como permite a captação de lacunas motoras que ordenam a acção.

Relembre-se, a título de exemplo, o fluxo ininterrupto de um agir poético em As Ondas, de Virginia Woolf, ou em A Morte de Virgílio, de Hermann Broch, onde quatro movimentos, água, fogo, terra e éter, tentam reedificar a descontinuidade do mundo. Não estamos perante aquilo que é usual chamar-se prosa poética - conceito vulgarizado quase até ao esvaziamento -, mas diante do que poderia apelidar-se de pensamento poético, tendo como ponto de partida uma corrente de consciência encontrada, embora de um outro modo, em Joyce, Kafka e Proust. É a energia da ideia, enquanto corpo de tracção, que pontua a pulsação do texto, ficando, portanto, o andar integrado na dança e vice-versa, adequação que nada tem, embora possa parecer, de paradoxal.

No domínio da dança, foi Steve Paxton, iniciador do Contact Improvisation, quem, de forma particular, desenvolveu, nos anos 60/70, a aproximação motora do caminhar, acrescentando-lhe, porque combatia então métodos coreográficos que considerava ditatoriais, nuances hipnóticas a partir do efeito de repetição/improvisação. Não terá sido inócua a presença na sua obra - bem como na de Merce Cunningham - de áreas do conhecimento como a Fenomenologia ou a Filosofia Zen que os opuseram, pelo lado do despojamento, aos movimentos heróicos dos vocabulários tradicionais.

Prosa e poesia, para Valéry, servem-se das mesmas palavras, da mesma sintaxe, das mesmas formas, sons e timbres, mas, na visão do autor de Analecta, a primeira dissolve-se na clareza, age, faz compreender, torna-se linguagem útil, exprime desejos, ordens, opiniões, desaparecendo ao transformar-se em algo outro no espírito do leitor. O poema, esse, no seu entendimento, "não morre por ter vivido", dir-se-ia uma "máquina produtora de estados poéticos" que renasce das cinzas como a fénix:

Ainsi, entre la forme et le fond, le son et le sens, entre le poème et létat de poésie, se manifeste une symétrie, une égalité d'importance, de valeur et de pouvoir, qui nest pas dans la prose ; qui soppose à la loi de la prose - laquelle décrète l'inégalité des deux constituants du langage. Le principe essentiel de la mécanique poétique - c'est-àdire des conditions de production de létat poétique par la parole - est à mes yeux cet échange harmonique entre l'expression et l'impression.» (VALÉRY, 2002, p. 682)

Esta ideia pendular e dicotómica (expressão/impressão) de oposição entre prosa e poesia (andar/dançar) - a meu ver contestável e, quanto aos aspectos coreográficos, totalmente datada -, dir-se-ia, não obstante, 
indissociável dos conceitos de memória e esquecimento sem os quais a escrita se torna fenómeno impossível: há que esquecer o passado recente para reencontrar o passado antigo; a vida-escrita necessita, no contexto de uma lembrança autodevoradora e prisioneira, da morte simbólica do Outro, algo que se pode aplicar tanto a factos materiais como psíquicos. "Eu sou obrigada a esquecer-te para te escrever". Por isso todo o texto se faz de camadas geológicas e envolve, segundo Rui Magalhães, dois textos, o que se dá a ler e o subterrâneo, "incerto no seu espaço/tempo, numa dimensão de imperceptibilidade e de incompreensibilidade, de perda para o significativo". Dele, do texto-corpo, emerge aquilo que chamou de voz nua, uma voz fora do eu, do mundo, do corpo, elevada dele próprio, "que não é a sua $v o z$, mas a voz que menos conflitua com ele", nascendo da sua matéria, não da sua vontade, porque "no corpo infinito [aquele que se espanta e espanta cada vez que toca ou é tocado] não há vontade imanente." (MAGALHÃES, 2006, p. 157-169)

A proximidade entre memória e esquecimento não é somente de ordem metafórica. Relembre-se que, nas sociedades africanas, o deus dir-se-ia recordação, um e múltiplo, materializado por disposições históricas, significando a suprema transgressão de a ele (memória activa) se querer voltar, algo que, de alguma forma, a escrita faz se não a associarmos meramente à consciência psicológica imediata ou intelectual. Nesse sentido, escrever poderia significar o retorno secreto e sensível às exigências e valores da noite do inconsciente, algo que a antropologia romântica fez gravitar em redor desse não-lugar ontológico - o nó misterioso que conduz à criação.

\section{O andar em Doutor Fausto}

Importa, porém, deslindar em que consiste o andar, para melhor se compreender a relação estabelecida por Valéry com a prosa. Não se trata de uma maquilhagem teatral que o corpo adopta, algo que apaga o rosto e o redesenha para o colocar num mundo outro. O conceito de persona (importante em Fernando Pessoa) tem, no entanto, de ser trazido à colação, no sentido que Jung lhe atribui enquanto função psíquica relacional voltada para o exterior, algo que se opõe à sizígia (animus/anima), responsável pela adaptação ao mundo interno e pela personificação espontânea do inconsciente.

$\mathrm{O}$ andar introduz a sensação do mundo, é um método (in)tranquilo de encantamento da durée $e^{8}$ (BERGSON, 2009) e do espaço: implica um estado de espírito, uma humildade feliz indiferente à técnica e aos meios de deslocação, ou pelo menos relativiza-os. O homem que caminha sente a aspereza da terra e a necessidade de reconciliação com a respiração e a beleza fracturada da sua condição. Esse género de peregrinação constitui uma forma deambulatória de homenagear o genius loci (espírito do lugar). Relembre-se, em Doutor Fausto, de António Vieira, o momento em que a personagem caminha pela noite, sentindo as vibrações do seu ser e da natureza:

Saiu uma noite para o frio da montanha: seguiu por transfiguradas sendas da floresta - e o tempo, o espaço, o corpo, e o próprio cosmos, tornaram-se estranhos. Quando se extinguiu a luz a que se guiava, sentiu-se perante a opacidade absoluta dos elementos, emparedado 
por uma muralha de trevas: e conheceu a intimidade de divindades terríveis, das divindades mais secretas do Ser, que julgava longínquas mas enfim o tocavam e de todos os lados o cercavam - Noite, Caos e Cronos, saídos da primeira geração dos deuses, e imperecíveis... (VIEIRA, 1991, p. 136)

Mais adiante, Fausto pergunta, antes de invocar o Espírito da Terra, que fará o cosmos da sua angústia imensa, reduzi-la-á a nada? Que poder teria aquele "céu côncavo, da grande abóbada envolvente"? Que mediação proporcionaria entre "as pulsações da vida e as abismosas questões abertas sobre a morte"? (VIEIRA, 1991, p. 137). A digressão não é aqui somente prosadora, mas poético-filosófica, como se este romance epistemológico girasse, à semelhança de uma gigantesca nora, em torno de um ponto: o conhecimento - quem sou eu e por que sofro?

$\mathrm{Na}$ verdade, o círculo, e não só na perspectiva formal, dir-se-ia neste livro um ponto dançável que pode transformar-se em espiral constelatória, projecção da esfera, da unidade primordial, conduzindo-nos à busca de um saber como. Vemo-lo participar, pela sua indivisibilidade, da perfeição do mundo (como nos lembra a tradição islâmica), mas, ao distanciar-se da unidade central, permite, no desenvolvimento de uma fenomenologia, que tudo se multiplique como o pensar sobre as coisas do mundo real.

É isso que Fausto faz no seu trilho mágico: proustianamente rememora, ama, delira, conduzido pela invenção, ofendido pela morte, torna-se vertigem porque afinal o caos estava dentro de si, detém-se, enquanto caminha, sobre coisas, imagens, fantasias, actos, sentimentos, interroga-se sobre o porquê dos homens. Como em Nietzsche, a exigência é de síntese entre arte e ciência, literatura e espírito de exactidão; como em Husserl, a consciência define as relações essenciais entre sujeito cognoscente e objecto conhecido. $\mathrm{O}$ universo não surge, nesta obra, enquanto composição mecânica, pressente-se, a todo o momento, a vitalidade da realidade intersubjectiva e histórica.

António Vieira ousa ser, a um só tempo, prosador-poeta, pensador e homem de ciência. Ensaio sobre o Termo da História (2009) virá a coroar de eficácia esta herética tríade, mas não esqueçamos que é caminhando, a partir de uma dança dos elementos, dos animais e da paisagem, que Doutor Fausto se desenvolve. Trata-se, na verdade, de um não-romance (no sentido musiliano), entranhado por um saber teórico, da filosofia à antropologia. Não pode, não obstante, deixar de ser visto, na sua trajectória de envios, remissões internas e externas, como um laboratório que pensa a condição humana à qual a experiência da linguagem e do imaginário confere visão, estranheza e transgressão.

Enquanto "observatório gigantesco" sobre o mundo, Doutor Fausto, na sua tragicidade, remete, por outro lado, o leitor para uma reflexão constante sobre a arte e o literário não alheada do espaço Blanchot - o romance é-lhe, aliás, dedicado. Na medida em que a emergência do Outro na narrativa, algo teatral, se rege, tantas vezes, pela lógica da dissemelhança e do desconhecido, torna-se precária a presença de Eurídice e invisível a de Margarida, talvez porque o telescópio por onde a personagem vê, "acima dos humanos”, seja afinal um filtro e não tanto um espelho. Nesses aspectos, a 
obra é mais fiel ao Fausto de Goethe do que a qualquer outro, embora o entendimento da alquimia em António Vieira não seja, pelo menos conscientemente, "uma das vias de acesso ao mundo divino" (CENTENO, 2007, p. 78).

As mulheres-insecto que povoam esta ficção vão, por outro lado, do solar ao lunar - relembre-se Flamiffera ou Cicindela -, e não deixam de ser fantasmagóricas, voláteis, na medida em que vão desaparecendo ao ritmo da viagem interior/exterior de Fausto que vive a dissimetria no campo amoroso. É no "movimento incessante" da escrita, tão apolínea quanto dionisíaca, que o autor se revela, porém, nesse jogo entre bem-estar teórico e mistério latente apenas derrubado pela angústia da perda do mundo.

Apesar do seu discurso fragmentário, Doutor Fausto dir-se-ia uma obra una construída a partir de uma involuntária vontade tratadista, acompanhada pelo pensar, entre outros, do já citado Blanchot, Bataille, Kafka, Agamben, Valéry. Não obstante a sua arquitectura de raiz sinfónica, por vezes wagneriana, há momentos, movimentos rapsódicos, variações de tema, intensidade e improvisações que a tornam tão exuberante e abundantemente impiedosa para com o leitor, como suave na transfiguração da natureza enquanto metáfora da alma sensível. Conjugando-se ficção, aforismo e ensaio, a ideia de inacabamento invade todo o texto e não apenas o seu fim, o que o torna moderno por assistematização. De alguma forma, a marcha reconduz Fausto a uma filosofia primeira, consente a metamorfose do olhar sobre o universo. Na medida em que sai do seu quarto, é o anti-Pessoa, que tenta também responder às questões fundadoras da condição humana: De onde venho, quem sou? Para onde vou?

\section{Dança do inconsciente}

Trata-se do aprender a dançar de Nietzsche, consciente o ser humano da sua condição intemporal, como sublinha Rui Magalhães ao referir que, numa continuidade fracturada, passamos a estar no domínio do intenso que "é o movimento no qual o ser se apaga como origem, como horizonte, como consistência." Imagine-se uma bailarina a girar, que faz ela senão isso mesmo? Conforme explica o ensaísta, o intenso (eu diria a dança) é a não-história, "a nulificação da acção, a exclusividade do movimento" (a mulher rodando sobre si própria), ao contrário do absoluto ("a narrativa circular de si mesma para a qual a História tende"), que é discreto e subtil (MAGALHÃES, 2008, p. 48). Nesse sentido, o ser que anda pode ser ou não um bailarino do inconsciente.

Fausto aprendeu a lição de Homero sobre a dança, sabe que esta se situa entre a cidade e o labirinto, círculo mágico por dentro do ser humano. Seguindo a lição de Baudelaire, reconhece, por outro lado, que o mundo é uma floresta de símbolos. Dyonisus, o duas vezes nascido, deus andrógino da plenitude e do excesso, cortado em pedaços pelos titãs e cozinhado (relembre-se o paralelismo com o mito egípcio de Osíris), reconstitui-se, dançando, algo que a poesia faz. Dançar, neste caso, significaria mais do que andar, o mesmo que deambulação no sentido benjaminiano; impossibilidade de dissociação do olhar a que se refere Rilke, algo que contraria a ideia do autor de Variété: "Aprendo a ver. Não sei por que motivo, tudo penetra em mim mais profundamente e não se imobiliza no ponto em que se costumava extinguir. Tenho uma interioridade que desconhecia. Tudo agora para aí se encaminha. Não sei o que aí se passa”. (RILKE, 2003, p. 37) 
Ao tomar consciência, durante a caminhada por Paris, da enorme quantidade de rostos que há, Rilke vê a multiplicidade do seu Eu: o(s) seus "rosto(s) por dentro", exactamente como Pessoa, cujo desassossegado andar por Lisboa traz em si uma vivência poliédrica e o teatro de um corpo angustiado. Não estamos necessariamente perante uma estética da vida quotidiana; é notória, porém, nesta prosa pensada, a relevância da cadência de ritmos, dos acordes e das discordâncias do andar de todos os dias: o passo dir-se-ia a acção de alternância entre o peso dos pés no chão, algo que Zaratustra não esquece quando desenha círculos sanguíneos em torno de si próprio: "Écrit de ton sang et tu apprendras que le sang est esprit." (NIETZSCHE, 1963, p. 51)

Quando escreve os seus híbridos romances iniciáticos, Yvette K. Centeno, arrancando à experiência uma tematização fenomenológica, parte, por outro lado, do quotidiano e do abissal desmoronamento interior para uma intuitiva ascese. O andar favorece, "saltitante e imperfeito", o pensamento à maneira de Jean-Jacques Rousseau, dir-se-ia palavra-acto, mais do que promessa. Palavra e acontecimento não são inseparáveis nestas narrativas, mas verbo eficaz. Não é o escritor um "viajante (caminhante, viandante?) solitário"? (ROUSSEAU, 1964). Dessa oposição entre velocidade e lentidão sanguínea faz-se esta escrita labiríntica - porque reconduz às profundezas do inconsciente - de lisura clara-escura.

Os romances-ensaio de Yvette K. Centeno - que desfiam infinitos dispersos-unos num trabalho concêntrico de palavra-poço que o leitor tem de decifrar - são ainda quase-diários, poesia e crónica, cenas-estilhaço às quais não falta um sentido lúdico da vida, como se a dor desabasse em riso (ou o contrário), desenhando mapas de imaginação e mistério. Poderiam também ser entendidos como teatros-lago que simbolizam o olho da terra por meio do qual os habitantes do mundo subterrâneo (inconsciente) podem olhar os seres humanos. Mais do que reproduzir desejos, a ficcionista toma-os por realidades e caminha, num ritmo oscilatório e perturbador, como escreve, No Jardim das Nogueiras, para demolir, trazendo ao de cima a informação criadora (logos, davar): "Criar é demolir. O artista é um homem que parte nas várias acepções desta palavra." (CENTENO, 1998, p. 31) Parte e parte, destrói e eleva as "partes de um círculo" que são interiormente destruídas: "A obra é o que resta dessa destruição. Inscrita num todo reenvia ao todo (de) que partiu." O círculo é vida, de onde vimos, e morte, para onde vamos, algo que Blanchot pensa de modo espectral quanto à arte que vê como imagem cadavérica. Nos livros de Yvette, pelo contrário, Lázaro ergue-se do túmulo para tomar a palavra. Foi preciso morrer para tomar a palavra.

Só falta a esta escrita gritar como no poema de Rilke, autor bem-querido de Yvette K. Centeno, entre sonhos e despertares intranquilos, no sobressalto de uma "eterna viagem", uma "terna viagem", "uma viragem”. E explica a autora "o $\mathrm{r}$ aqui não é gralha. De resto há gralhas que são coincidências significativas. Mas não é gralha, é escolha” (CENTENO, 2006, p. 38). R de quê, perguntar-se-á o leitor? Porque não há caminho sem pergunta e é isso que estes romances são: percursos que conduzem ao centro de uma teia de aranha, cujo perplexo fio constitui um símbolo de liberdade e libertação, epifania lunar a tentar fugir da aparência ilusória e em busca de uma realidade suprema na dialéctica entre existência e essência. Nessa duplicidade entre interrogação e (não)resposta, funda-se a sistematização livre da narrativa repartida entre a sombra e a máscara, o espectro e o reflexo, a simbologia e a alquimia da palavra/corpo. 


\section{Yvette e o desassossego pessoano}

Yvette K. Centeno define, por outro lado, o caminho de Pessoa e o lugar que nele ocupa a influência hermética como se a autora o experienciasse ela própria: "Já o desassossego é o estado de alma própria do adepto na sua fase de nigredo, da angústia e do desespero, quando se lança na 'busca'. E o livro [do Desassossego] é diário, é o roteiro, é o guia do labirinto da alma perdida e achada nessa aventura." No ensaio "A Filosofia Hermética na Obra de Fernando Pessoa" (CENTENO, 1988, p. 104-05), a escritora de Matriz, aludindo ao "saber pensar e saber sentir" pessoano, explora a ideia do movimento, ligando-a ao jogo. Este é inseparável das dimensões rituais associadas à trilogia totalidade, regra e liberdade, ao diálogo do homem com o invisível.

Ao querer sentir tudo de todas as maneiras, o poeta exprime-se, esclarece, "na explosão, no rodopio das formas e das circunferências, tentando, não já recuperar o centro que ele pensa e sente perdido, mas a projecção, os desdobramentos até o ponto extremo da anulação do eu (da consciência do eu)." (CENTENO, 1988, p. 104-05) Geometria e abismo são, segundo a ensaísta, as imagens que o definem na vertigem do inconsciente que se organiza pela palavra por meio da qual o sonho falha, segundo Pessoa, até nas metáforas e figurações. É a esse exercício, a esse andar poético, desejado e recusado, que Bernardo Soares sombriamente se refere em O Livro do Desassossego.

Não é tédio o que se sente. Não é mágoa o que se sente. É uma vontade de dormir com outra personalidade, de esquecer com melhoria de vencimento. Não se sente nada a não ser um automatismo cá em baixo, a fazer umas pernas que nos pertencem levar a bater no chão, na marcha involuntária, uns pés que se sentem dentro dos sapatos. Nem isto se sente talvez. À roda dos olhos e como dedos nos ouvidos há um aperto de dentro da cabeça.

Parece uma constipação na alma. E com a imagem literária de se estar doente nasce um desejo de que a vida fosse uma convalescença, sem andar. (PESSOA, 2001, p. 109)

Podemos considerar Pessoa impaciente, mas anda e por vezes dança, quase sentado, mas dança, organizando-se a si próprio num processo de construção de tensões espaciais que permitem o suporte dinâmico do movimento na corêutica ${ }^{10}$ aplicada a todos os domínios da vida (corpo-alma-espírito). Segundo Laban (DANSE, 1999, p. 698), "o movimento é o espelho mágico do ser humano ${ }^{11}$ " e que será a escrita se não isso mesmo? Como Baudelaire, o poeta transforma essa sua agitação em explosão de jogo aparentemente frustrado. Ao sentir-se espoliado de si mesmo e em fuga perante o negro de dentro, move-se sem se conseguir mover, descentrado do Eu e das possíveis ligações ao concreto exterior, à palavra, aos outros enfim, tornando a vida em obra literária.

Ao transformar a sua escrita num virtuosismo virtual, Pessoa faz, todavia, da rua um palco cercado e concentrado numa moderna melancolia, consciente de que a viagem o nauseia, apesar do mistério intangível do universo: "Ah, viagem os que não existem!" (PESSOA, 2001, p. 143). Vai, no entanto, errando (errando de errância ou de errar?) pela cidade, na sua tristeza dispersa. Nela contraditoriamente, diz "gozar" com a dinâmica de 
um bailarino que se move de forma pré-reflexiva, atento, no seu quase-frio alheamento, ao movimento dos outros. E é nesse passeio lento pelo entrecruzar das ruas que a tristeza aumenta e se faz prosopoema com uma "violência súbita e estonteante".

Haveria que viajar por dentro da obra ficcional de Yvette K. Centeno à luz do Livro do Desassossego, de Bernardo Soares, ou d'As Anotações de Malte Laurids Brigge, de Rainer Maria Rilke, concebendo-se a viagem enquanto escada, esfera, labirinto, conhecimento dentro do conhecimento filtrado por uma clareza de densidade feita de monólogos/diálogos interiores. Como não vê-los a estes três escritores - cuja correspondência a três poderia imaginar-se -, como líricos, poético-filosóficos, prosadores bailarinos ou bailarinos da prosa? Só o lirismo, na sua concretude possível, é capaz de realizar essa unidade antinómica porque não passa tão-só pela memória mas por um interior oculto de intensa condensação e vigilância.

Trata-se, como no sistematizado andar-dança, de um método que utilizam, embora não dirigido, mas de ordem musical; de um comentário lírico, sendo o estilo apenas a superfície das coisas, algo também marcante em Doutor Fausto, de António Vieira, tal como o conceito de labirinto, tradicionalmente entendido enquanto sistema de defesa, não só contra o adversário humano, mas contra o mal (não é a sua representação uma mandala?). Estas narrativas, vistas a quatro dimensões, são peregrinação religiosa no sentido do que re-liga. A busca de um "mistério supremo" existe, no entanto, sobretudo em Pessoa e Rilke, actualizando Yvette K. Centeno um caminho de enovelados fios que estes autores também percorreram, esses tais "abismos sobre os quais, lá em cima, correm as nuvens", como refere Walter Benjamin (2006, p. 178).

Abismos de cima, abismos de baixo: cedo se aprende, como esclarece Yvette K. Centeno, em Matriz, que não há morte, mas progressos e recuos, movimento que a palavra move, só que nela reside também o perigo porque "a mesma palavra que anima pode vir a matar." (CENTENO, 1988, p. 57-61) A construção formal dos seus romances não é, porém a da submissão a um modelo hegemónico, a composição passa não pela ideia de uma coreografia, mas pela da improvisação, jazzística ou não.

Se, pela sua dimensão aleatória, a improvisação tem a vantagem de conduzir o acto composicional às prerrogativas de um Eu criador, não lhe confere, porém, estabilidade. Não se trata de explorar um tema, nestes romances, mas de escrever dentro de um laboratório que fornece a matriz da invenção do movimento de onde nascerá a obra; não se cria uma partitura de signos lisíveis, mas pesquisáveis, à qual a ideia de orchésalité não é alheia (do grego orchêsis, dança, de onde deriva a palavra orquestra enquanto origem do espaço teatral ou coro que dançava). Está-se no domínio da criação de mitos e da modulação interna da exploração motora de um corpo mental. As personagens de Yvette K. Centeno querem tornar-se radicalmente outras.

Não há, aparentemente, na sua obra, um esforço de ordenação coreográfico-poética. Acontece. Sempre surge um signo que orienta o movimento na sua ébria função. O "todo coerente" a que a autora se refere (CENTENO, 1998, p.195) guia-se por sinais ou símbolos, constrói-se enquanto aprendizagem. O lugar desta escrita dir-se-ia o do espaço epistemológico, tanto no campo da transcendência como da imanência. Como 
se ordenam ensinamentos se a escrita jorra por entre sombras e interditos? Em cada letra desperta um mar transparente, embora oculto, das significações, sendo o caminho não de estrelas, mas de pedras. Diz a ficcionista: “Temos de as engolir." (CENTENO, 1998, p. 220) Pedra-água, pedra-verbo, pedra-misteriosa e transmutadora que, de tanto se ingerir, se espalha e se dissolve num todo universal.

À semelhança de Rilke, de Pessoa ou de um Michaux, a poeta de Perto da Terra desenha com o corpo da mão desejando ver a $n$ dimensões. E o desenho dir-se-ia, como afirma no seu último romance (CENTENO, 2011, p. 9), o da própria vida: "O que se eterniza é o permanente movimento." (CENTENO, 2011, p. 34) Não há retorno sem movimento, mesmo que não se saiba bem a QUÊ, e está-se sempre a retroceder para voltar mais forte. Talvez por isso, o conjunto ininterrupto das narrativas-laboratório de Yvette K. Centeno constituam um único livro, o seu Livro do Desassossego ou Livro de Estilhaços, porque contêm em si uma dinâmica de metamorfose, sendo feitas não só de palavras-símbolo mas de vida que dá e queima, oferece e devora, esconde e ilumina.

Há como que um jogo aleatório de construção e desconstrução da unidade aparente de uma corporeidade, a que se refere Michel Bernard, e que não cessa de se dissolver na sucessão dos instantes nesta obra viandante. Só que o corpo é espírito e, se se torna gesto determinado por um móbil positivo, produz, pelo seu carácter germinativo, efeitos de ascensão. Ou seja, liga quem tem de ser ligado. Nesse sentido, a obra de Yvette K. Centeno também pode ser compreendida como dança improvisada, prosa dançável que, por vezes, deixa de ser ficção e se converte em ensaio ou diário, crónica ou comentário. Tem, amiúde, a forma sincopada e polirrítmica do jazz, utilizando o seu padrão dialogante, dir-se-ia melodia e contra-melodia evoluindo num processo de dispersão e concentração. Ao deslocar-se por caminhos outros como os dos sonhos - dissolvidos no indefinido até se clarificarem -, devolve-nos a ideia do vaso alquímico enquanto crânio, redondo/esférico, ou romã. Fiando e desfiando um tecido, assemelha-se a um vestido-véu volátil, o de Loïe Fuller, é corpo pertencente à terra, de onde se desprende para a ela voltar, ou instrumento musical, talvez um saxofone porque o som vem das profundezas.

\section{Silêncio caminhante}

Nessa medida, pode dizer-se que jamais dançamos em silêncio como jamais escrevemos em silêncio. $\mathrm{O}$ mistério nestes romances fragmentários e inacabados não passa somente pela sua magia ou melancolia, mas pela sensação de presença (a dos ratos no sótão, das baratas pela casa, da música que se ouve e se esquece, do "pêssego amarelo vermelho macio sumarento" que se come [CENTENO, 1994, p. 201-03]). A ficção de Yvette K. Centeno mantém o candelabro aceso mesmo quando, de noite, todos repousam: nela as imagens formam-se e dá-se corpo à palavra. O silêncio caminha, estrepitoso, embora lentamente, embala e desinquieta. Se o desassossego de Pessoa é implosivo, o da autora entra e sai em retirada da caverna da existência, convive com os outros no quotidiano, com os filhos, os amigos, os místicos e os alquimistas, os autores bem-amados e os artistas, os que estão e os que já partiram. Pertence ao reino dos anjos e dos homens, pensa com eles, como se o mundo fosse visto a uma outra velocidade recheada das vibrações sonoras e coloridas de um quadro de Chagall. 
Nada é separado, tudo está e não está no mesmo plano. Em Do Longe e do Perto (CENTENO, 2011), os netos chegam, a erudição transmite-se, despretensiosa, Portugal grita por ordenação e sentido, são amargos os clamores de um mundo sem redenção, denuncia-se uma sociedade bloguista que na internet encontrou, por outro lado, um espaço de liberdade, tão perigoso quanto eventualmente frutífero. Aqui e ali, o amor questiona-se e o diálogo com um Deus que nos "seduz e tortura" surge, denso, pontuando a reflexão profunda sobre a passagem do tempo: "caminhos do caminhar que é a vida" em busca da alma fugida de Bernardim (que antecipa, segundo diz, Mallarmé e Pessoa), e de onde este livro parte: Menina e $M o c ̧ a$, a que levaram de casa de seu pai para longes terras, entrelaçada com a rota epistolar de Diotima.

\section{Conclusão}

O viandante sábio sabe que não há lugar santo. É a nossa forma de caminhar sobre a terra que a torna sagrada. Rilke, Pessoa, Vieira ou Yvette percorrem-na de pés alados, deslocando-se dentro de si próprios enquanto sujeitos desejantes. $\mathrm{O}$ primeiro tenta corresponder à sua noção exacta de imobilidade, solitário e poeta, procurando entre as coisas visíveis o equivalente às suas visões interiores; move-se e vê a escrita nascer-lhe das mãos como vasos sanguíneos de pródigo e prodigioso atalho. O segundo, consciente de que a sua alma é uma orquestra oculta, ensurdece com a sinfonia dissonante que sente ser, sabe que a estrada não tem curva, reconhecendo, por isso, que nunca vai chegar. $\mathrm{O}$ terceiro, no seu racionalismo sensível, caminha, lúcido, pelas vértebras do tempo, conturbado pelos sinais do incaracterístico - o de uma sociedade constrangida pelo poder, o mercantilismo, a burocracia e o medo - transformando a porção de trevas de obscuridade íntima em luz. Cria uma obra entre a fenomenologia e a literatura, narrativa de ideias que "passa além", inesperada e avassaladora. Única mulher deste quarteto, Yvette estremece com as pequenas coisas como quem escuta as asas de uma borboleta ou a forma contraditória de agir da natureza. E, quando assina o seu nome, fá-lo de longe para que as palavras não firam/sangrem em demasia.

Todos eles Rilke, Pessoa, Vieira, Yvette, caem erguem-se, na sua prosa veloz, devastados pela singularidade da angústia. Amparam-nos os anjos, doces ou terríficos. Todos se erguem do escuro de um seu tempo espectral em litanias ferozes ou subtis que fazem estremecer a terra. Não é a prosa que os preserva, mas a poesia com quem dançam até à morte como em Der Tod un das Mädchen, de Schubert ${ }^{12}$.

\section{Notas}

1 Depois de Saussure, a distinção entre língua e palavra tornou-se clássica.

2 Tradução minha.

3 Relembre-se a epígrafe de Le Livre des Questions, de Edmond Jabès (2002): “Tu es celui qui écrit et qui est écrit."

4 “Toda a palavra é enfadonha e ninguém é capaz de explicá-la”.

5 Sublinhado meu.

6 Bailarino, coreógrafo, maître de ballet e teórico da dança. 
$7 \mathrm{Na}$ sequência desse raciocínio, Laban considerou ainda que o ponto de convergência de todas as direcções constitui a $27^{\text {a }}$ direcção, denominada lugar (place).

8 Durée e simultaneidade são duas formas de pensar as relações entre os sistemas temporais e o movimento no universo.

9 Trata-se uma segunda versão do original publicado em 1994.

10 Parte do corpo teórico de Laban concernente às possibilidades direccionais do movimento humano no espaço. Forma e dinâmica são, a seu ver, inseparáveis. Na opinião do investigador, por trás do trajecto aparente do movimento, esconde-se o movimento infinito e eterno do mundo.

11 Laban utiliza o termo coreosofia - do grego, chorós, grupo de bailarinos e cantores que participavam nas representações teatrais e festividades religiosas, ou dança de roda em coro, e sophia, sabedoria-conhecimento - para designar o conjunto de saberes práticos e teóricos concernentes à dança.

12 Excerto do poema de Matthias Claudius: “Der Tod: Gib deine Hand, du schön und zart Gebild!/Bin Freund, und komme nicht, zu strafen./ Sei gutes Muts! ich bin nicht wild,/ Sollst sanft in meinen Armen schlafen!”. "Dá-me a tua mão, ó bela e terna forma/ Sou uma amiga, nada tens a temer/ Anima-te, não sou cruel,/ Dormirás docemente em meus braços!” Tradução minha.

\section{Referências Bibliográficas}

AGAMBEN, Giorgio. Idée de la prose. Trad. de Gérard Macé. Paris: Christian Bourgois, 1998.

BENJAMIN, Walter. Charles Baudelaire: Um Poeta na Época do Capitalismo Avançado, «Parque Central» in - A Modernidade. Edição e tradução de João Barrento. Lisboa, Assírio \& Alvim, 2006.

BERGSON, Henri. Durée et simultanéité. 4. ed. Paris: PUF, 2009.

BERNARD, Michel. Esquisse d'une problématique des rapports de la danse et de la musicalité. Disponível em http://www.philagora.net/philo/ danse-mus1.php.

BROCH, Hermann. A Morte de Virgílio. Trad. Maria Adélia Silva Melo. Lisboa: Relógio d’Água, 1988. 2 v.

CENTENO, Yvette K. Amores Secretos. Lisboa: Edições Asa, 2006.

. Do Longe e do Perto - Quase-Diário. Lisboa: Sextante, 2011.

. Fernando Pessoa, Os Trezentos e Outros Ensaios, Lisboa: Editorial Presença, 1988.

. Os Jardins de Eva. Lisboa: Edições Asa, 1998.

. Matriz, Lisboa: Editorial Presença, 1988.

. Teatro e Sociedade. Lisboa: Edições Universitárias Lusófonas, 2007.

. Três Histórias de Amor, «As Palavras que Pena», Lisboa, Edições Asa, 1994.

CHEVALIER, Jean; GHEERBRANT, Alain. Dictionnaire des Symboles. Paris: Robert Laffont/Jupiter, 2005.

CUSA, Nicolau de. A Douta Ignorância. Tradução, introdução e notas de 
João Maria André. Lisboa: Ed. Fundação Calouste Gulbenkian, 2003.

JABÈS, Edmond. Le Livre des Questions. Paris: Gallimard, 2002.

BÍBLIA. Português. Bíblia Sagrada. ed. revista e aumentada, São Paulo: Edições Paulinas, 1985.

LACOUE-LABARTHE, Philippe; NANCY, Jean-Luc. L'Absolu Littéraire: Théorie de la Littérature du Romantisme Allemand. Paris: Seuil, 1978.

LE MOAL, Philippe (org.). Dictionnaire de la danse. Paris: Larousse, 1999.

MAGALHÃES, Rui. Infinito Singular - Sobre o Não-Literário. Alcochete: Textiverso, 2006.

. Literatura e Vida. Centro de Línguas e Culturas da Universidade de Aveiro, 2008.

NIETZSCHE, Friedrich. Ainsi parlait Zarathoustra. Trad. Maurice Betz, Apresentação Henri Thomas. Paris: Livre de Poche, 1963.

PAZ, Octavio. El Arco y la Lira. Madrid: Fondo de Cultura Económica de España, 2004.

PESSOA, Fernando - Livro do Desassossego Composto por Bernardo Soares. Ajudante de Guarda-Livros na Cidade de Lisboa. Edição de Richard Zenith. Lisboa: Assírio \& Alvim, 2001.

PONGE, Francis Pratiques d'écriture ou l'inachèvement perpétuel. Paris: Hermann édit., 1984.

RILKE Rainer Maria, As Anotações de Malte Laurids Brigge. Trad. e Prefácio de Maria Teresa Dias Furtado. Lisboa: Relógio d’Água, 2003.

Paul Frères, 1946.

Journal florentin. Trad. de Maurice Betz. Paris: Éditions Emile-

ROUSSEAU, Jean-Jacques. Les Rêveries du promeneur solitaire. Cronologia. e Prefácio de Jacques Voisine. Paris: Flammarion, 1964.

SARTRE, Jean-Paul Sartre. Situations II. Paris: Gallimard, 1948.

VALÉRY, Paul. Variété. Paris, Gallimard, 2002. v. III, IV e V.

VIEIRA, António. Doutor Fausto. Lisboa: Imprensa Nacional-Casa da Moeda, 1991.

Ensaio sobre o Termo da História - Trezentos e Sessenta e Cinco Aforismos contra o Incaracterístico. Lisboa: Fim de Século, 2009.

WOOLF, Virginia. As Ondas. Trad. de Francisco Vale. Lisboa: Relógio d’Água, 1988.

(Recebido para publicação em 12/11/2010,

Aprovado em 15/12/2010) 